\title{
Implementasi Model Pembelajaran SAVI terhadap Motivasi, Kemandirian dan Hasil Belajar Mahasiswa di Mata Kuliah Sistem Informasi Akuntansi
}

\author{
${ }^{1}$ Linawati, ${ }^{2}$ Hestin S.W. \\ Program Studi Akuntansi, Universitas Nusantara PGRI Kediri, Indonesia \\ Email: ${ }^{1}$ linawati@unpkediri.ac.id ${ }^{2}$ hestinsri@unpkediri.ac.id
}

\section{Tersedia Online di}

http://www.jurnal.unublitar.ac.id/i ndex.php/briliant

\section{Sejarah Artikel \\ Diterima pada 12 April 2020 \\ Disetujui pada 27 April 2020 \\ Dipublikasikan pada 30 Mei 2020 \\ Hal. 232-240}

\section{Kata Kunci:}

Motivasi; Kemandirian; Hasil

Banjar; SAVI

\section{DOI:}

http://dx.doi.org/10.28926/briliant. v3i4.457

Dapat diambil kesimpulan bahwa diterapkannya model pembelajaran SAVI dapat meningkatkan motivasi, kemandirian dan hasil belajar mahasiswa Prodi Akuntansi pada mata kuliah SIA.

\section{PENDAHULUAN}

Pendidikan merupakan ujung tombak untuk menciptakan sumberdaya manusia yang unggul. Pemerintah terus berupaya untuk meningkatkan kualitas pendidikan. Upaya pemerintah dalam memperbaiki kualitas pendidikan, dilakukan melaui berbagai upaya, misalnya meningkatkan anggaran untuk pendidikan, memperbaiki kurikulum, menambah penyediaan sarana dan prasarana pendidikan, dan meningkatkan profesionalisme tenaga pendidik (guru atau dosen). Pada peningkatan profesionalismenya, guru dan dosen harus meningkatkan dan mengembangkan kemampuan pedagogiknya. Kemampuan yang harus dikembangkan salah satunya yaitu kemampuan dalam pelaksanaan proses pembelajaran. Proses pembelajaran merupakan suatu sistem, yang melibatkan guru atau dosen dengan siswa atau mahasiswa. Dalam proses pembelajaran peran guru atau dosen mempunyai pengaruh yang cukup banyak dan penting. Guru atau dosen harus mampu memberikan kreativitas proses pembelajaran melalui penerapan model pembelajaran yang bervariasi untuk merangsang siswa atau mahasiswa aktif dalam pelaksanaan proses belajar. 
Mata kuliah di bidang akuntansi bercirikan dengan banyak materi menghitung dan menganalisis. Diperlukan ketelitian dan pemahaman tinggi untuk belajar akuntansi. Salah satu mata kuliah yang membentuk kompetensi keahlian dalam bidang akuntansi adalah mata kuliah Sistem Informasi Akuntansi (SIA). Mata kuliah SIA mempelajari tentang peran penting sistem informasi dalam mendukung pengendalian internal suatu entitas. Topik - topik dalam mata kuliah SIA meliputi informasi sebagai sistem, pengendalian internal, dan peran pengendalian internal yang dipergunakan untuk pengambilan keputusan. Dalam mata kuliah SIA ini diperlukan banyak analisis terutama dalam pelaksanaan pengendalian internal. Hal tersebut menuntut penguasaan teori dan praktik.

Hasil pengamatan peneliti (sebagai dosen) pada proses pembelajaran mata kuliah SIA pada mahasiswa Prodi Akuntansi Universitas Nusantara PGRI Kediri, ketercapaian hasil belajar mahasiswa belum maksimal. Terlihat pada nilai Ujian Tengah Semester (UTS) Semester Ganjil 2019-2020 pada mata kuliah SIA, nilai rata-rata mahasiswa hanya 61,96 . Ketercapaian nilai tertinggi 86 dan nilai terendah 40. Permasalahan lain yang ditemukan diantaranya mengenai aspek motivasi dan kemandirian belajar mahasiswa. Fakta yang terjadi saat proses pembelajaran, banyak mahasiswa yang tidak mengerjakan tugas, acuh tak acuh saat perkuliahan berlangsung, tidak disiplin saat pengumpulan tugas, saling mencontek tugas teman lain, dan kurang kerjasama dalam kelompok. Fenomena tersebut mengindikasikan bahwa motivasi mahasiswa dalam belajar mata kuliah akuntansi masih rendah. Dengan motivasi belajar yang rendah tersebut menciptakan kemandirian belajar mahasiswa juga rendah. Rendahnya motivasi dan kemandirian belajar, akan berpengaruh pada hasil atau prestasi belajarnya.

Permasalahan yang terjadi pada pembelajaran tersebut, perlu dilakukan upaya tindakan perbaikan, agar kualitas pembelajaran meningkat. Dosen dapat mengupayakan perbaikan tersebut dengan memvariasi strategi pembelajaran, supaya pembelajaran lebih menarik dan efektif. Strategi pembelajaran dapat berupa metode, pendekatan, ataupun model pembelajaran. Model pembelajaran adalah suatu perencanaan atau suatu pola untuk membentuk kurikulum, perancangan materi pembelajaran dan sebagai acuan pembelajaran (Rusman, 2012). Sangat banyak dan beragam model pembelajaran yang ada saat ini. Model pembelajaran saat ini menuntut peserta didik untuk aktif, sehingga pembelajaran dilakukan dengan terpusat pada peserta didik, dan pendidik berperan sebagai fasilitator. Model pembelajaran SAVI (Somantis, Auditori, Visual, Intelektual) merupakan salah satu model pembelajaran yang berpusat pada peserta didik, sehingga peserta didik dituntut untuk aktif pada proses pembelajaran. Somantis berarti menggerakkan tubuh, auditori berarti mendengarkan dan berbicara, visual berarti melihat, mengamati, menggambarkan, dan intelektual berarti berpikir kritis memecahkan permasalahan. Dalam model pembelajaran SAVI peserta didik secara aktif mengikuti proses pembelajaran dengan aktif menggerakkan anggota tubuhnya, menggunakan semua indra yang dimiliki untuk aktif dalam pembelajaran. Harapannya proses pembelajaran menjadi maksimal.

Model pembelajaran SAVI merupakan pembelajaran dengan melibatkan indra pada tubuh, memanfaatkannya sebanyak mungkin, sehingga membuat seluruh tubuh atau pikiran terlibat dalam proses belajar (Meier, 2005). Penekanan model pembelajaran SAVI yaitu pada pemanfaatan semua panca indra peserta didik (Wijayanti, Prayitno, \& Marjono, 2013). Kusumawati, (2014) menyatakan 
pembelajaran SAVI salah satu pembelajaran dengam menekankan kebermaknaan belajar melalui aktivitas mendengarkan dan menyimak, berbicara, berargumentasi, berpendapat, menanggapi dan berpikir kritis untuk meningkatkan konsentrasi pikiran melalui penalaran, penyelidikan, pengidentifikasian, dan pemecahan masalah. Adapun Menurut Ekawati (2019), model pembelajaran SAVI menyatukan keterampilan gerak, visual, audio, dan kognitif dalam memahami materi. Pada model pembelajaran SAVI peserta didik diberikan kesempatan untuk menggunakan dan memanfaatkan panca indranya sebanyak dan semaksimal mungkin dalam kegiatan pembelajaran. Peserta didik dalam proses pembelajarannya secara tidak langsung harus aktif, kreatif, keterlibatan secara langsung, sehingga menemukan secara mandiri apa yang dipelajarinya.

Sejalan dengan karakteristik dalam matakuliah SIA, model pembelajaran SAVI dianggap relevan untuk diterapakan pada matakuliah SIA. Pada matakuliah ini, mahasiswa dituntut untuk dapat mereplikasi, mendesain, menggambarkan, dan menganalisis SIA pada sebuah entitas untuk mendukung pengendalian internalnya. Dalam matakuliah SIA mahasiswa harus aktif dan menggunakan lebih banyak panca indranya, agar proses belajar dapat lebih efektif. Misalnya mahasiswa harus dapat menggambar bagan alir sistem informasi, maka membutuhkan keterampilan dalam melakukannya. Dibutuhkan motivasi yang tinggi untuk mempelajari materi - materi dalam SIA, karena membutuhkan analisis, evaluasi dan praktik. Motivasi belajar mahasiswa adalah faktor utama penentu keberhasilannya dalam belajar. Mahasiswa dengan motivasi belajar tinggi, akan dapat menciptakan kemandirian belajar secara mandiri. Kemandirian belajar adalah tanggung jawab dalam mengembangkan dan meningkatkan kemampuan dan kemauan sendiri, tanpa bergantung pada orang lain (Sumawardani \& Faif Pasani, 2016). Jika motivasi sudah terbentuk, maka kemandirian belajar akan terwujud dengan sendirinya, sehingga ketuntasan hasil belajar akan tercapai dengan maksimal.

Mencermati permasalahan tersebut, maka model pembelajaran SAVI di rasa sangat baik untuk dipraktikkan dalam pembelajaran SIA. Hasil penelitian diharapkan mampu mendeskripsikan peningkatan motivasi belajar, kemandirian belajar, dan hasil belajar mahasiswa pada mata kuliah SIA, setelah diterapkannya pembelajaran dengan model pembelajaran SAVI. Hasil penelitian ini juga menambah bukti empiris bahwa model pembelajaran SAVI dapat memfasilitasi mahasiswa untuk belajar dengan lebih baik dan efektif.

\section{METODE}

Penelitian ini dilaksanakan pada semester ganjil 2019-2020, setelah Ujian Tengah Semester (UTS) di Prodi Akuntansi Fakultas Ekonomi dan Bisnis Universitas Nusantara PGRI Kediri. Subyek penelitian adalah mahasiswa semester $\mathrm{V}$, dengan obyek penelitian meliputi motivasi, kemandirian dan hasil belajar mahasiswa pada matakuliah SIA menggunakan model pembelajaran SAVI.

Penelitian ini berjenis penelitian tindakan kelas (Classroom Action Research). Penelitian dilakukan secara kolaborasi dengan sejawat dosen lain sebagai kolabolator. Kolaborasi dilakukan mulai tahap observasi, perencanaan, dan pelaksanaan, serta refleksi. Penelitian dilaksanakan pada minggu ketiga sampai dengan akhir semester ganjil 2019-2020. Model rancangan penelitian tindakan kelas menggunakan rancangan model Kemmis dan Taggart (dalam Tampubolon, 2014). Pelaksanaanya menggunakan 2 siklus. Disetiap siklus terdiri dari 4 tahapan, 
yaitu (1) penyusunan perencanaan (planning), (2) pelaksanaan tindakan (acting), (3) observasi (observing), (4) refleksi (reflecting).

Data dikumpulkan melalui observasi, tes, dan dokumentasi. Penggunaan tes untuk mengukur hasil belajar mahasiswa dengan pemberian kuis secara on-line, dan tes tertulis. Observasi dengan instrumen lembar observasi digunakan untuk mengetahui motivasi dan kemandirian mahasiswa selama mengikuti perkuliahan dengan model pembelajaran SAVI. Setelah data terkumpul dan ditabulasi, selanjutnya melakukan analisis. Analisis data menggunakan analisis deskriptif dengan mendeskripsikan peningkatan motivasi, kemandirian belajar dan ketuntasan hasil belajar mahasiswa.

\section{HASIL}

Penelitian tindakan kelas ini dilakukan dengan dua siklus. Setiap siklus dilakukan dengan empat tahapan, yaitu tahapan perencanaan, tahapan pelaksanaan, tahapan pengamatan dan tahapan refleksi. Setiap siklus dalam penelitian tindakan kelas ini dilakukan sebanyak dua kali pertemuan, dengan materi sistem informasi akuntansi pada siklus pengeluaran.

Berikut ini paparan hasil penelitian yang meliputi rekapitulasi motivasi mahasiswa, kemandirian belajar mahasiswa, dan hasil belajar mahasiswa.

\section{Tabel 1: Hasil obeservasi motivasi belajar mahasiswa}

\begin{tabular}{|c|c|c|c|c|c|c|c|c|c|}
\hline No. & Indikator observasi & \multicolumn{4}{|c|}{ Siklus 1} & \multicolumn{4}{|c|}{ Siklus 2} \\
\hline 1 & $\begin{array}{l}\text { Minat dan perhatian } \\
\text { mahasiswa terhadap mata } \\
\text { kuliah }\end{array}$ & 3 & tinggi & 3 & tinggi & 3 & tinggi & 4 & $\begin{array}{l}\text { sangat } \\
\text { tinggi }\end{array}$ \\
\hline 2 & $\begin{array}{l}\text { Reaksi mahasiswa terhadap } \\
\text { stimulus dari dosen }\end{array}$ & 2 & rendah & 3 & tinggi & 3 & tinggi & 4 & $\begin{array}{l}\text { sangat } \\
\text { tinggi }\end{array}$ \\
\hline 4 & $\begin{array}{l}\text { Tanggung jawab dalam } \\
\text { mengerjakan tugas }\end{array}$ & 2 & rendah & 3 & tinggi & 3 & tinggi & 3 & tinggi \\
\hline 5 & $\begin{array}{l}\text { Rasa senang dan puas } \\
\text { mengerjakan tugas }\end{array}$ & 2 & rendah & 2 & rendah & 3 & tinggi & 4 & $\begin{array}{l}\text { sangat } \\
\text { tinggi }\end{array}$ \\
\hline
\end{tabular}

Sumber: Data diolah (2020)

Tabel 2: Rekapitulasi observasi motivasi belajar mahasiswa

\begin{tabular}{|c|c|c|c|c|}
\hline \multirow[t]{2}{*}{ Keterangan } & \multicolumn{2}{|c|}{ Siklus Satu } & \multicolumn{2}{|c|}{ Siklus Dua } \\
\hline & $\begin{array}{c}\text { Pertemuan } \\
\text { Ke-1 }\end{array}$ & $\begin{array}{c}\text { Pertemuan } \\
\text { ke-2 }\end{array}$ & $\begin{array}{c}\text { Pertemuan } \\
\text { Ke-1 }\end{array}$ & $\begin{array}{c}\text { Pertemuan } \\
\text { ke-2 }\end{array}$ \\
\hline Rata-rata nilai & 11,8 & 13,2 & 15,0 & 17,2 \\
\hline Peningkatan tiap pertemuan & - & 1,4 & - & 2,2 \\
\hline Rata-rata nilai tiap siklus & \multicolumn{2}{|c|}{12,5} & \multicolumn{2}{|c|}{16,1} \\
\hline Peningkatan pada siklus & \multicolumn{4}{|c|}{3,6} \\
\hline
\end{tabular}

Sumber: Data diolah (2020)

Motivasi belajar diukur menggunakan indikator yang dikembangkan oleh Ayu Astira, dkk (2013), yaitu (1) minat dan perhatian mahasiswa terhadap mata kuliah, (2) reaksi mahasiswa terhadap stimulus dari dosen, (3) semangat mahasiswa dalam mengikuti perkuliahan dan melaksanakan tugas, (4) tanggung jawab mengerjakan tugas, (5) rasa senang dan puas mengerjakan tugas. Pengambilan data dengan lembar observasi, berskala likert dengan skor 1 sampai dengan 4. Skor 1 
opsi sangat rendah, skor 2 opsi rendah, skor 3 opsi tinggi, dan skor 4 opsi sangat tinggi.

Berdasarkan tabel 1, dari indikator -indikator dalam penilaian motivasi belajar mengalami peningkatan pada pertemuan ke pertemuan. Pada indikator pertama, yaitu minat dan perhatian mahasiswa terhadap mata kuliah, mempunyai nilai dengan kriteria tinggi di pertemuan pertama siklus pertama menjadi sangat tinggi pada pertemuan kedua di siklus kedua. Pada indikator kedua, yaitu reaksi mahasiswa terhadap stimulus dari dosen, mengalami kenaikan dari pertemuan ke pertemuan, yang awalnya rendah menjadi sangat tinggi. Pada indikator ketiga, yaitu semangat mahasiswa dalam mengikuti perkuliahan dan melaksanakan tugas-tugas, mengalami kenaikan dari pertemuan ke pertemuan, yang awalnya rendah menjadi tinggi. Pada indikator keempat, yaitu tanggung jawab dalam mengerjakan tugas, mengalami kenaikan dari pertemuan ke pertemuan, yang awalnya rendah menjadi tinggi. Adapun pada indikator kelima, yaitu rasa senang dan puas mengerjakan tugas, mengalami kenaikan dari pertemuan ke pertemuan, yang awalnya rendah menjadi sangat tinggi.

Berdasarkan tabel 2, pada siklus I, dipertemuan pertama nilai rerata motivasi mahasiswa 11,8, sedangkan dipertemuan kedua nilai reratanya 13,2 mengalami peningkatan 1,4. Pada Siklus II, dipertemuan pertama nilai rerata motivasi mahasiswa 15,0, sedangkan dipertemuan kedua reratanya 17,2 mengalami peningkatan 2,2. Nilai rereta motivasi belajar di siklus I sebesar 12,5, dan meningkat di siklus II, nilai reratanya menjadi 16,1 . Secara keseluruhan motivasi mahasiswa dalam belajar meningkat dari siklus 1 ke siklus 2, dengan peningkatan sebesar 3,6.

Tabel 3: Hasil obeservasi kemandirian belajar mahasiswa

\begin{tabular}{|c|c|c|c|c|c|c|c|c|c|}
\hline \multirow[b]{2}{*}{ No. } & \multirow[b]{2}{*}{ Indikator observasi } & \multicolumn{4}{|c|}{ Siklus 1} & \multicolumn{4}{|c|}{ Siklus 2} \\
\hline & & $\begin{array}{c}\text { Pertemu } \\
\text { an ke-1 }\end{array}$ & $\begin{array}{c}\text { Krite- } \\
\text { ria }\end{array}$ & $\begin{array}{c}\text { Pertemu } \\
\text { an ke-2 }\end{array}$ & $\begin{array}{c}\text { Krite- } \\
\text { ria }\end{array}$ & $\begin{array}{c}\text { Pertemu } \\
\text { an ke-1 }\end{array}$ & $\begin{array}{c}\text { Krite- } \\
\text { ria }\end{array}$ & $\begin{array}{c}\text { Pertemu } \\
\text { an ke-2 }\end{array}$ & $\begin{array}{c}\text { Krite- } \\
\text { ria }\end{array}$ \\
\hline 1 & $\begin{array}{l}\text { Mempunyai sumber belajar } \\
\text { yang beragam }\end{array}$ & 2 & rendah & 3 & tinggi & 3 & tinggi & 4 & $\begin{array}{l}\text { sangat } \\
\text { tinggi }\end{array}$ \\
\hline 2 & $\begin{array}{l}\text { Memiliki kepercayaan diri } \\
\text { dan keyakinan untuk } \\
\text { menyelesaikan tugas }\end{array}$ & 2 & rendah & 3 & tinggi & 3 & tinggi & 3 & tinggi \\
\hline 3 & $\begin{array}{l}\text { Mengerjakan tugas secara } \\
\text { mandiri dan penuh } \\
\text { tanggung jawab }\end{array}$ & 2 & rendah & 3 & tinggi & 3 & tinggi & 3 & tinggi \\
\hline 4 & Berperilaku disiplin & 3 & tinggi & 3 & tinggi & 4 & $\begin{array}{l}\text { sangat } \\
\text { tinggi }\end{array}$ & 4 & $\begin{array}{l}\text { sangat } \\
\text { tinggi }\end{array}$ \\
\hline 5 & $\begin{array}{l}\text { Rasa puas terhadap tugas } \\
\text { yang dikerjakan }\end{array}$ & 2 & rendah & 2 & rendah & 3 & tinggi & 4 & $\begin{array}{l}\text { sangat } \\
\text { tinggi }\end{array}$ \\
\hline 6 & $\begin{array}{l}\text { Mempunyai keinginan } \\
\text { berprestasi }\end{array}$ & 2 & rendah & 3 & tinggi & 3 & tinggi & 3 & tingigi \\
\hline
\end{tabular}

Sumber: Data diolah (2020)

Tabel 4: Rekapitulasi Hasil Tingkat Kemandirian Belajar Mahasiswa

\begin{tabular}{|lcccc|}
\hline \multirow{2}{*}{ Keterangan } & \multicolumn{2}{c}{ Siklus Satu } & \multicolumn{2}{c|}{ Siklus Dua } \\
\cline { 2 - 6 } & $\begin{array}{c}\text { Pertemuan } \\
\text { Ke-1 }\end{array}$ & $\begin{array}{c}\text { Pertemuan } \\
\text { ke-2 }\end{array}$ & $\begin{array}{c}\text { Pertemuan } \\
\text { Ke-1 }\end{array}$ & $\begin{array}{c}\text { Pertemuan } \\
\text { ke-2 }\end{array}$ \\
\hline rata-rata nilai & 13,8 & 15,4 & 18,4 & 20,6 \\
\hline peningkatan tiap pertemuan & - & 1,6 & - & 2,2 \\
\hline rata-rata nilai tiap siklus & \multicolumn{3}{c}{14,6} & \multicolumn{3}{c|}{19,5} \\
\hline peningkatan pada siklus & \multicolumn{3}{c}{4,9} \\
\hline
\end{tabular}

Sumber: Data diolah (2020) 
Pengukuran kemandirian belajar, dengan indikator sebagai berikut: (1) Mempunyai sumber belajar yang beragam, (2) Mengerjakan tugas secara mandiri dan penuh tanggung jawab, (3) Memiliki kepercayaan diri dan keyakinan untuk menyelesaikan tugas, (4) Berperilaku disiplin, (5) Rasa puas terhadap tugas yang dikerjakan, (6) Mempunyai keinginan berprestasi. Pengambilan data dengan lembar observasi, menggunakan ukuran skala likert skor 1 sampai dengan 4. Nilai skor 1 opsi sangat rendah, skor 2 opsi rendah, skor 3 opsi tinggi, dan skor 4 opsi sangat tinggi.

Berdasarkan tabel 3, dari indikator -indikator dalam penilaian motivasi belajar mengalami peningkatan pada pertemuan ke pertemuan. Pada indikator pertama, yaitu mempunyai sumber belajar yang beragam, mempunyai nilai dengan kriteria tinggi di pertemuan pertama siklus pertama menjadi sangat tinggi pada pertemuan kedua di siklus kedua. Pada indikator kedua, yaitu mengerjakan tugas secara mandiri dan penuh tanggung jawab, mengalami kenaikan dari pertemuan ke pertemuan, yang awalnya rendah menjadi sangat tinggi. Pada indikator ketiga, yaitu memiliki kepercayaan diri dan keyakinan untuk menyelesaikan tugas, mengalami kenaikan dari pertemuan ke pertemuan, yang awalnya rendah menjadi tinggi. Pada indikator keempat, yaitu berperilaku disiplin, mengalami kenaikan dari pertemuan ke pertemuan, yang awalnya rendah menjadi tinggi. Pada indikator kelima, yaitu rasa puas terhadap tugas yang dikerjakan, mengalami kenaikan dari pertemuan ke pertemuan, yang awalnya rendah menjadi tinggi Adapun pada indikator keenam, yaitu mempunyai keinginan untuk berprestasi, mengalami kenaikan dari pertemuan ke pertemuan, yang awalnya rendah menjadi sangat tinggi.

Berdasarkan tabel 4, siklus I, di pertemuan pertama tingkat kemandirian belajar mahasiswa memperoleh nilai rerata 13,8 , pertemuan kedua nilai reratanya sebesar 15,4 mengalami peningkatan 1,6. Siklus II di pertemuan pertama tingkat kemandirian belajar mahasiswa memperoleh nilai rerata 18,4 , sedangkan di pertemuan kedua nilai reratanya 20,6 mengalami peningkatan 2,2. Didapatkan nilai rerata siklus I, sebesar 14,6 dan nilai rerata di siklus II sebesar 19,5. Secara keseluruhan tingkat kemandirian belajar mahasiswa mengalami perubahan yaitu meningkat pada siklus 1 ke siklus 2, dengan peningkatan 4,9.

Tabel 5: Rekap Hasil belajar mahasiswa

\begin{tabular}{|lcc|}
\hline \multicolumn{1}{|c}{ Uraian } & Siklus Satu & Siklus Dua \\
\hline Rata-rata (Mean) & 66,1 & 76,90 \\
\hline Modus & 72,5 & 83,5 \\
\hline Belum tuntas (\%) & $30 \%$ & $18 \%$ \\
\hline Tuntas (\%) & $70 \%$ & $82 \%$ \\
\hline Peningkatan ketuntasan (\%) & - & $12 \%$ \\
\hline
\end{tabular}

Berdasarkan pada tabel 5 di atas, nilai rerata mahasiswa di siklus pertama sebesar 66,10, sedangkan siklus kedua nilainya sebesar 76,90. Terlihat ada peningkatan nilai dari hasil belajar mahasiswa. Mahasiswa yang dinyatakan tuntas belajar semakin banyak. Mahasiswa yang dinyatakan tuntas belajar pada siklus pertama sebesar 70\%, atau berjumlah 15 mahasiswa yang tidak tuntas dalam belajar. Pada siklus kedua jumlah mahasiswa yang tidak tuntas belajar berkurang 
menjadi 9 mahasiswa, dari total 49 mahasiswa, dengan persentase ketuntasan sebesar $82 \%$.

\section{PEMBAHASAN}

Hasil penelitian tindakan kelas yang dilaksanakan pada mata kuliah SIA selama dua siklus, mendapatakan hasil bahwa motivasi belajar, kemandirian belajar, dan hasil belajar mahasiswa pada mata kuliah SIA dengan materi siklus pengeluaran menunjukkan peningkatan dari siklus I ke siklus II. Hal ini tidak terlepas dari penerapan model pembelajaran SAVI pada pelaksanaan pembelajaran.

Pelaksanaan model pembelajaran SAVI pada mata kuliah SIA saat dilakukannya penelitian tindakan kelas ini, mahasiswa dituntut untuk aktif dalam menggunakan panca indranya. Pada materi sistem informasi akuntansi pada siklus pengeluaran, mahasiswa di setiap pertemuan diadakan pre-test atau post-test dengan media kuis on line. Pemberian kuis secara on line ini agar mahasiswa lebih bersemangat dalam belajar, karena pelaksanaan kuis seperti permainan game online, sehingga antusias dan keinginan mahasiswa untuk mengerjakan kuis semakin meningkat. Mahasiswa dalam belajar juga dituntut menggunakan teknologi informasi, seperti mahasiswa harus mampu menggambar bagan alir dengan menggunakan aplikasi Ms. Visio, selain menggambar bagan alir secara manual. Pada proses pembelajaran ini, mahasiswa harus menggunakan panca indranya dengan baik. Mahasiswa diminta mengikuti tutorial teknik menggambar menggunakan Ms. Visio yang dipandu oleh dosen. Mahasiswa harus mendengarkan, melihat, mengamati dan menggerakkan anggota tubuhnya (tangan) untuk menggambar bagan alir sistem sesuai dengan kasus yang ada. Mahasiswa juga ditugaskan untuk melakukan survei lapangan mengenai sistem informasi akuntansi pada siklus pengeluaran, misalnya pembelian, retur pembelian, dan pengeluaran kas pada unit bisnis yang ada di sekitar tempat tinggal mahasiswa. Berdasarkan hasil survei, selanjutnya mahasiswa melaporkan dalam bentuk makalah dan mempresentasikan hasilnya.

Untuk mengetahui motivasi belajar dan kemandirian belajar mahasiswa pada materi sistem informasi pada siklus pengeluaran dengan menerapkan model pembelajaran SAVI, digunakan lembar observasi. Penilaian pada lembar observasi dilakukan oleh observer yaitu dosen dan dosen kolaborator pada saat proses pembelajaran berlangsung.

Hasil pengamatan yang dilakukan selama pelaksanaan penelitian, menunjukkan adanya perubahan perilaku belajar mahasiswa, yaitu pada aspek motivasi dan kemandirian belajarnya. Motivasi belajar mahasiswa meningkat di setiap pertemuan, baik pada siklus I ataupun siklus II. Dari lima indikator pengamatan, indikator minat dan perhatian mahasiswa terhadap mata kuliah, serta reaksi mahasiswa terhadap stimulus yang diberikan dosen meningkat secara kontinyu, dari nilai rentang rendah menjadi sangat tinggi. Model pembelajaran SAVI yang melibatkan secara aktif panca indra, secara tidak langsung mendorong motivasi belajar mahasiswa. Misalnya pada pelaksanaan pembelajaran, mahasiswa diminta untuk mereplikasi gambar bagan alir baik secara manual ataupun dengan aplikasi komputer, mengerjakan kuis secara on line, kegiatan tersebut membuat mahasiswa tidak bosan dan lebih semangat pada proses pembelajaran. Hal ini sejalan dengan pendapat Uno (2008) yang menyatakan motivasi merupakan dorongan internal dan eksternal untuk peserta didik yang sedang belajar dengan 
upaya mengadakan perubahan tingkah laku, dengan beberapa indikator atau unsur yang mendukung. Motivasi peserta didik akan mempengaruhi pada proses belajar dan hasil belajarnya. Peserta didik yang termotivasi dalam belajar, akan berbeda pada pelaksanaan proses belajarnya.

Hasil pengamatan pada kemandirian belajar mahasiswa, menunjukkan peningkatan di setiap pertemuan, baik pada siklus I ataupun siklus II. Dengan model pembelajaran SAVI, aktifnya mahasiswa baik dari fisik maupun pikiran, memacu mahasiswa untuk lebih mandiri untuk belajar. Terlihat pada hasil pengamatan, pada indikator pertama, yaitu keanekaragaman sumber belajar, terus mengalami peningkatan pada tiap pertemuan. Dari awalnya rendah menjadi sangat tinggi. Demikian pula pada indikator kedisiplinan dan rasa puas terhadap penyelesaian tugas yang diberikan juga meningkat di setiap pertemuannya. Misalnya, diberikannya kuis secara on line, tugas observasi ke lapangan dan mempresentasikan hasilnya, membuat mahasiswa terpacu untuk menyelesaikan tugas dengan menambah sumber belajarnya sendiri dan menyelesaikan tepat waktu. Hal ini menunjukkan bahwa dituntutnya mahasiswa untuk aktif dalam proses pembelajaran, secara tidak langsung akan mendorong semangat dan keinginan belajarnya. Hal tersebut menciptakan kemandirian dalam belajar. Sejalan dengan pendapat Rusman, (2012) kemandirian belajar ditunjukkan dengan meningkatnya kemampuan dan ketrampilan peserta didik dalam proses belajar secara mandiri. Kemandirian belajar mengajarkan peserta didik untuk belajar dengan aktif untuk menguasai kompetensi materi pelajaran yang dibangun dengan pengetahuan yang dimilikinya. Untuk membangun kemandirian belajar peserta didik, pendidik diwajibkan memberikan pengalaman belajar yang menumbuhkan rasa senang, puas pada peserta didik, serta membantu mencari informasi yang diperlukan.

Pencapaian hasil belajar mahasiswa, diukur menggunakan pre-test, posttest dan tes tertulis. Pada ketuntasan hasil belajar mahasiswa, menunjukkan meningkatnya hasil belajar pada siklus pertama ke siklus kedua. Hal ini ditunjukkan dengan meningkatnya nilai rerata hasil belajar mahasiswa, yang diikuti dengan bertambahnya jumlah mahasiswa yang dinyatakan tuntas belajar. Hal ini sejalan dengan pendapat Sudjana, (2011), bahwa hasil belajar ditandai berubahnya tingkah laku yang mencakup aspek kognitif, afektif, dan psikomotor. Berubahnya ketiga aspek tersebut dapat diukur dengan tes tertulis berkaitan dengan materi pembelajaran.

Hasil pelaksanaan penelitian tindakan kelas yang dilakukan, implemetansi model pembelajaran SAVI pada mata kuliah SIA, memberikan peluang bagi mahasiswa untuk dapat belajar lebih baik. Memotivasi mahasiswa untuk belajar lebih semangat dan menciptakan kemandirian belajar yang mandiri atau tinggi. Secara tidak langsung berdampak pada peningkatan pencapaian hasil belajar mahasiswa. Model pembelajaran SAVI merupakan pembelajaran yang menyatukan gerakan fisik dengan aktivitas intelektual, dengan penggunaan semua panca indra yang mempengaruhi pada proses pembelajaran (Meier, 2005). Pembelajaran dengan model SAVI, menstimuli mahasiswa untuk melibatkan semua panca indranya dalam belajar. Model pembelajaran SAVI memusatkan pembelajaran pada mahasiswa. Dalam model pembelajaran SAVI, mahasiswa dituntut aktif dalam segala hal, seperti menggerakkan anggota tubuh, mendengarkan, melihat, mengamati, menginterpretasi dan berpikir kritis untuk memecahkan masalah. 


\section{KESIMPULAN}

Implementasi model pembelajaran SAVI yang melibatkan panca indra secara aktif dan maksimal, terbukti mampu meningkatkan motivasi, kemandirian, dan hasil belajar mahasiswa Prodi Akuntansi, di mata kuliah SIA. Hasil penelitian tindakan kelas yang telah dilaksanakan menunjukkan motivasi belajar mahasiswa yang meningkat dari siklus pertama ke siklus kedua. Kemandirian dalam belajar mahasiswa juga meningkat dari siklus pertama ke siklus kedua. Meningkatnya motivasi dan kemandirian belajar mahasiswa tersebut mendorong hasil belajar mahasiswa menjadi lebih baik. Hal ini dibuktikan dengan meningkatnya nilai rata - rata kelas pada materi siklus pengeluaran, pada tiap siklusnya. Mahasiswa yang tuntas dalam belajar semakin banyak, yaitu sebanyak $82 \%$.

\section{SARAN}

Berdasarkan pelaksanaan penelitian tindakan kelas yang dilakukan, model pembelajaran SAVI dapat diterapkan dalam pembelajaran akuntansi. Model pembelajaran tersebut mampu meningkatkan motivasi belajar, kemandirian belajar, dan hasil belajar mahasiswa, karena melibatkan seluruh panca indra sehingga proses belajar menjadi lebih efektif. Model pembelajaran SAVI dapat sebagai alternatif dan variasi dalam pelaksanaan pembelajaran pada matakuliah akuntansi yang lain, misalnya pada matakuliah akuntansi keuangan lanjutan, auditing, perpajakan, dimana matakuliah tersebut memerlukan analisis dan praktik.

\section{DAFTAR RUJUKAN}

Ayu Astira, Darsono, dan S. (2013). Tipe STAD untuk Meningkatan Motivasi dan Hasil Belajar PKn. Pedagogi, 1(4).

Ekawati, D. (2019). Pengembangan Model Pembelajaran SAVI (Somatis, Audiotoris, Visual Intelektual) Bermedia Video Pada Pembelajaran Drama Kelas Viii a Smpn 1 Menganti, Gresik Tahun Ajaran 2018/2019. Bapala, 5(2), $1-18$.

Kusumawati, S. W. (2014). Penerapan Model Pembelajaran SAVI Untuk Meningkatkan Keterampilan Pemecahan Masalah Di Sekolah Dasar PGSD FIP Universitas Negeri Surabaya. Jpgsd, 2(2), 1.

Meier, D. (2005). The accelerated learning handbook. Bandung: Kaifa.

Rusman. (2012). Model-model pembelajaran. Bandung: CV. Bina Media.

Sudjana, N. (2011). Penilaian hasil proses belajar mengajar. Bandung: Remaja Rosdakarya.

Sumawardani, W., \& Faif Pasani, C. (2016). Efektivitas Model Pembelajaran SAVI dalam Pembelajaran Matematika untuk Mengembangkan Karakter Mandiri Siswa. EDU-MAT: Jurnal Pendidikan Matematika, 1(1), 82-89. https://doi.org/10.20527/edumat.v1i1.576

Tampubolon, S. (2014). Penelitian tindakan kelas. Jakarta: Erlangga.

Uno, H. B. (2008). Teori motivasi \& pengukurannya. Jakarta: Bumi Aksara.

Wijayanti, T., Prayitno, B., \& Marjono, M. (2013). Pengaruh Pendekatan Savi Melalui Model Pembelajaran Kooperatif Tipe Stad Terhadap Hasil Belajar Pada Siswa Kelas Vii Smp Negeri 14 Surakarta. Jurnal Pendidikan Biologi Universitas Sebelas Maret, 5(1), 118814. 